Nalar: Jurnal Peradaban dan Pemikiran Islam

Vol. 3, No. 1, Juni 2019

\title{
Metodologi Pembaruan Neomodernisme dan Rekonstruksi Pemikiran Islam Fazlur Rahman
}

\author{
Ahmad Labib Majdi \\ Sekolah Pascasarjana Universitas Islam Negeri Syarif Hidayatullah Jakarta \\ abmad_labib17@mbs.uinjkt.ac.id
}

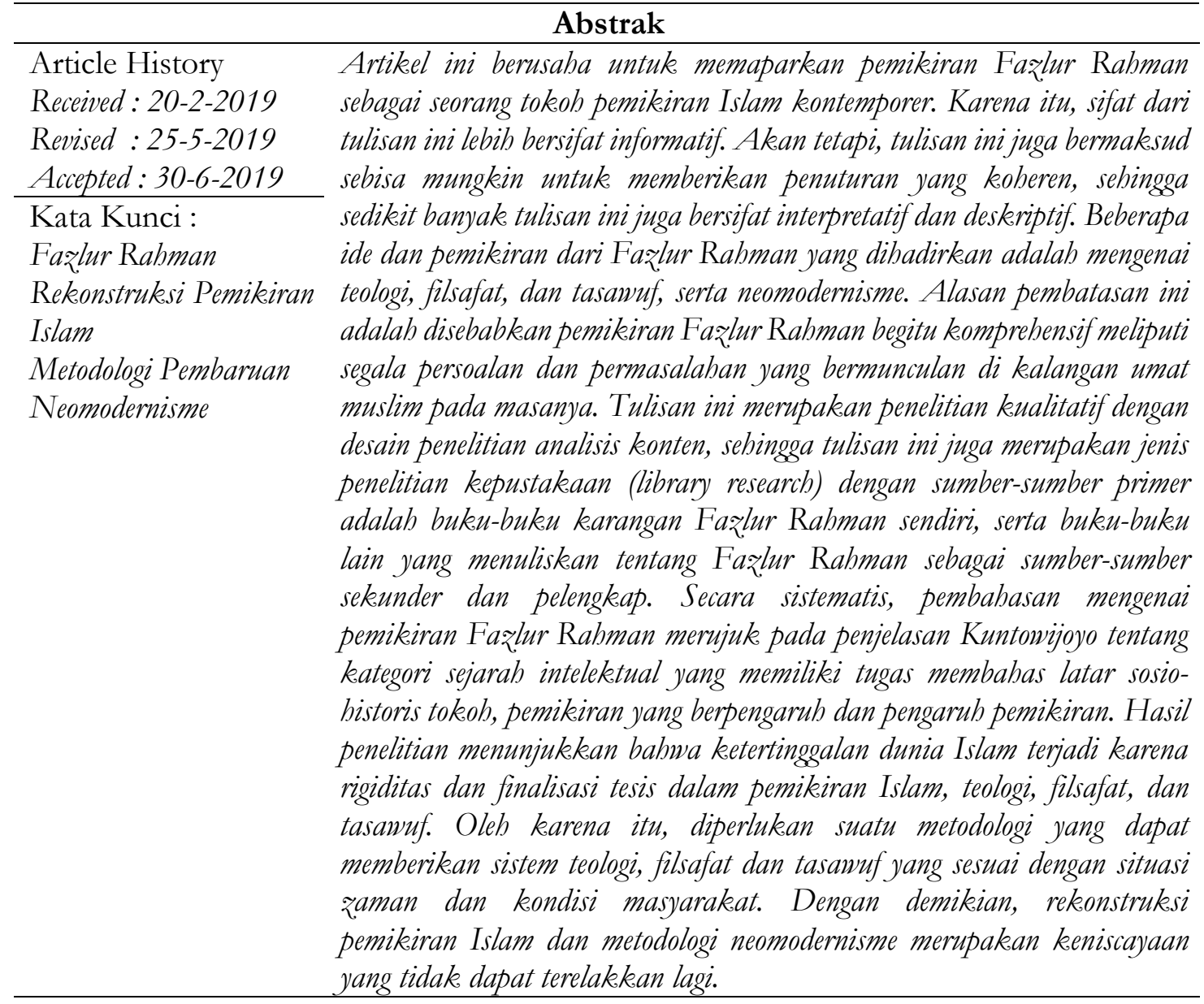

\section{Pendahuluan}

Secara umum, kaum muslim menganggap Islam sebagai sebuah ajaran dan nilai-nilai yang hak lagi sempurna. Sebagai sebuah ajaran dan nilai-nilai yang benar dan sempurna, Islam diyakini mampu menjamin kewujudan hidup yang lebih baik secara lahir maupun batin. Perwujudan ini dapat terealisasikan melalui pengembangaan makna substansi dari sumber pokok ajaran Islam. Namun, kebutuhan akan pengembangan tersebut tidak dapat dilakukan tanpa mendayagunakan pikiran dan nalar kritis. Oleh sebab itu, Islam sendiri melalui sumber pokoknya, alquran dan hadis, telah memberikan perhatian serius terhadap peranan daya pikir kritis terhadap diskursus mengenai ajaran Islam dan nilai-nilainya.

Seiring perkembangan diskursus tentang ajaran Islam, kemunculan pelbagai corak keberagamaan dalam Islam menjadi sebuah konsekuensi logis. Hal ihwal ini, tidak terlepas dari perbedaan, setidaknya, sudut pandang dan mentalitas yang menjiwai sebuah corak 
Nalar: Jurnal Peradaban dan Pemikiran Islam

Vol. 3, No. 1, Juni 2019

keberagamaan, terutama ketika menghadapi arus perubahan zaman; ada yang konfrontatif, ada yang apologetik dan ada yang akomodatif. Selain disebabkan oleh perkembangan diskursif yang disertai diversitas sudut pandang, kemunculan pelbagai corak keberagamaan juga karena anggapan kemunduran dan ketertinggalan dunia Islam dari dunia di luar Islam (Barat). Lebih lanjut, secara umum, masing-masing corak keberagamaan itu memiliki satu kesamaan, yakni menganggap sedang menampilkan corak keberagamaan Islam autentik dan otoritatif yang bermuara pada periode awal Islam.

Sepanjang sejarah pemikiran Islam yang diselubungi kabut ortodoksi, persoalan sumber pokok ajaran Islam dan makna substansinya bukan hanya samar-samar, tetapi juga telah menjadikan suatu teks atau hasil interpretasi terhadap teks bersifat otoriter dan ortodoks (Sirry, 2015:2). Fenomena ini terjadi paling tidak disebabkan oleh dua kesalahan utama. Pertama, kemunculan sikap yang memandang bahwa pemikiran dan ijtihad ulama terdahulu sebagai sesuatu yang baku dan final, yang akhirnya berujung pada suatu sikap menyakralkan terhadap segala peninggalan ulama klasik dan pertengahan. Kesalahan kedua adalah kemunculan bentuk pemahaman secara parsial dan tekstual terhadap teks keagamaaan tanpa memberikan perhatian serius, jika tidak dikatakan abai sama sekali, sebagian lain dari teks tersebut dan konteks sosio-historisnya.

Kesalahan pertama, setidaknya, berpengaruh pada keengganan untuk memikirkan ulang (rethinking) pemikiran-pemikiran itu. Alih-alih berharap muncul kreativitas untuk menelusuri secara langsung pada sumber pokok ajaran Islam, yang ada justru kemunculan klaim kebenaran dan klaim keselamatan berdasarkan pendapat ulama terdahulu yang diyakini benar. Sementara akibat dari kesalahan kedua adalah terjadi miskonsepsi atas kandungan teks, yang pada perkembangannya memunculkan anggapan bahwa makna yang benar adalah teks eksplisit itu sendiri. Konsekuensi dari anggapan ini adalah menolak kemunculan pandangan lain, sehingga yang berbeda akan dianggap bidah dan bahkan sesat (Aziz, 2009:71-72). Dengan demikian, dapat dikatakan, meski tampak simplikatif, kedua sikap ini yang justru menjadikan dunia Islam mengalami kemunduran serta ketertinggalan, dan yang terutama mengalami kejumudan intelektual, karena merasa cukup dengan ijtihad para ulama terdahulu.

Memasuki periode modern dan kontemporer, atas dasar fenomena-fenomena di atas muncul respon yang berupaya untuk mereformasi atau memikirkan ulang (rethinking) khazanah intelektual Islam periode klasik dan pertengahan yang kadung dianggap absolut, baku, final, dan sakral oleh sebagian kalangan muslim. Salah satu pionir dalam proyek reformation atau rethinking ini adalah Fazlur Rahman (selanjutnya ditulis Rahman), seorang intelektual muslim yang pernah menjadi Guru Besar di bidang pemikiran Islam pada Universitas Chicago. Dia dikenal sebagai pemikir muslim yang memiliki dasar keilmuan Islam yang kuat sekaligus tradisi intelektual Barat yang kritis (Hamid \& Yaya, 2010:182).

Intelektualitas dan intelegensia Rahman terlihat dari pelbagai gagasan yang dituangkan dalam sejumlah buku dan artikel, mulai dari bidang teologi, filsafat, tasawuf, hingga perkembangan Islam modern-kontemporer. Pengakuan atas perihal ini, jika boleh dikatakan, tidak hanya diakui dan dikenal oleh kalangan muslim an sich, melainkan juga di kalangan nonmuslim. Bahkan, dikatakan bahwa sesaat setelah dia meninggal, Universitas Chicago, tempatnya mengajar, konon harus menyiapkan empat profesor dengan empat keahlian dalam bidang berbeda untuk bisa menggantikan dirinya (Ditta, 2017). Keempat bidang yang dimaksud adalah teologi, filsafat, tasawuf, serta metodologi dan pembaruan Islam.

Sementara berhubungan dengan kejumudan berpikir kalangan muslim dan tantangan modernitas, Rahman berupaya untuk mengatasi pelbagai persoalan yang muncul dan menyadarkan kalangan muslim untuk memikirkan ulang beberapa pandangan yang melembaga dalam tradisi-tradisi yang diwariskan turun-temurun. Dalam konteks ini, Rahman 
Nalar: Jurnal Peradaban dan Pemikiran Islam

Vol. 3, No. 1, Juni 2019

melakukan dan menawarkan suatu rekonstruksi paradigmatik terhadap interpretasi arus utama yang cenderung tekstual-tradisional. Melalui teori gerakan ganda (double movement) yang digagasnya, Rahman menginginkan sebuah pemahaman yang aktual, relevan, dan tepat mengenai bidang subdoktrin ajaran Islam, terutama bidang teologi, filsafat, dan tasawuf.

Istilah rekonstruksi bersama dengan istilah konstruksi dan dekonstruksi, dapat dikatakan merupakan istilah kunci bagi para pemikir muslim kontemporer ketika mengajukan gagasannya. Secara sederhana, konstruksi dapat diartikan sebagai susunan dan hubungan makna yang terdapat dalam kajian kebahasaan (Sarwiji, 2008:63). Dalam kaitan dengan pemikiran Islam, konstruksi acapkali menunjukkan pada suatu pemikiran yang dianggap mapan dan ortodoks. Sementara istilah dekonstruksi dalam konteks pemikiran Islam, diartikan sebagai perombakan dan pembongkaran pemikiran mapan dan ortodoks dengan tujuan mengubah pemikiran itu menjadi relatif dan pemikiran yang ahistoris menjadi historis (al-Jabiri, 1991:48). Di antara tokoh yang menggunakan istilah dekonstruksi dalam pemikirannya adalah Mohammaed Arkoun, Abid al-Jabiri, dan Abdullah A. Naim.

Sementara istilah rekonstruksi dalam sejarah pemikiran Islam kontemporer, telah banyak digunakan juga oleh para pemikir muslim kontemporer, seperti Hassan Hanafi, Ashgar Engineer, dan juga Rahman. Hanafi (1992:27-29), salah seorang intelektual Mesir, menyatakan bahwa rekonstruksi pemikiran Islam adalah pembangunan kembali warisanwarisan Islam berdasarkan spirit modernitas dan kebutuhan muslim kontemporer. Secara praktiknya, Rahman (1982:141-146; Amal:146) menyatakan bahwa rekonstruksi pemikiran Islam adalah menelaah kesejarahan krisis Islam dan menawarkan suatu cetak biru (blue print) bagi transformasi kehidupan intelektual ke dalam suatu kekuatan kreatif dan vital. Dengan demikian, rekonstruksi pemikiran Islam di sini diartikan sebagai usaha Rahman dalam memberikan interpretasi baru, yang lebih menyentuh situasi dan kondisi kontemporer, terhadap khazanah pemikiran mapan dan ortodoks dengan tanpa menegasikannya.

Istilah yang juga perlu segera ditegaskan adalah neomodernisme. Dalam sejarah pemikiran Islam, istilah ini dimunculkan pertama kali oleh Rahman sendiri. Secara sederhana, neomodernisme merupakan gerakan intelektual Islam yang bersifat humanistis dan sarat dengan nilai-nilai etik Islam (A'la, 2003:1). Sebagaimana akan diuraikan nanti, neomdernisme adalah aliran/paham keislaman yang berupaya menyintesiskan antara dimensi keilmuan tradisional Islam, yang diwakili gerakan revivalisme dengan dimensi ilmu-ilmu sosial kritis dari pemikiran Barat, yang diwakili gerakan modernisme. Oleh karena itu, dalam tulisan ini, neomodernisme diposisikan bukan sebagai gambaran zaman atau era setelah modern, melainkan sebagai sebuah gerakan, atau aliran/paham intelektual dalam konteks sejarah pemikiran Islam.

Berpijak pada argumen di atas, tulisan ini berusaha menampilkan pemikiran Rahman yang berkaitan dengan rekonstruksi pemikiran Islam (teologi, filsafat Islam, dan tasawuf). Sebelum itu, penulis terlebih dahulu menjelaskan teori gerakan ganda yang ditawarkan Rahman, yang secara langsung diimplementasikan dalam setiap usaha rekonstruksinya. Penulis juga secara padat dan ringkas membahas tipologi gerakan pemikiran Islam yang dibagi oleh Rahman menjadi empat berdasarkan masa dan dominasi pemikiran saat itu. Keempat gerakan pemikiran Islam itu adalah revivalisme, modernisme, neorevivalis, dan neomodernisme.

Sejauh penelusuran penulis, banyak tulisan yang telah membahas tentang biografi intelektual Fazlur Rahman. Namun, sejauh itu pula, pembahasan mengenai pemikiran Rahman tentang rekonstruksi pemikiran Islam belum ditemukan. Dari hasil penelusuran atas karya sebelumnya, perbedaan mendasar tulisan ini dengan karya terdahulu terdapat pada fokusnya, di mana tulisan ini difokuskan untuk menguraikan rekonstruksi sistematis Rahman 
Nalar: Jurnal Peradaban dan Pemikiran Islam

Vol. 3, No. 1, Juni 2019

terhadap pemikiran teologi, filsafat, dan tasawuf sepanjang sejarah Islam. Secara khusus, dua bidang terakhir, filsafat dan tasawuf, menjadi nilai tambah tersendiri dalam tulisan ini. Dengan demikian, tulisan ini dapat diposisikan sebagai pelengkap dari kajian-kajian terdahulu tentang pemikiran Fazlur Rahman.

Agar tulisan ini terstruktur dan terarah, penulis perlu menegaskan metodologi yang digunakan. Penelitian ini dapat dikategorikan sebagai penelitian sejarah pemikiran atau intelektual yang dalam praktiknya mengambil satu asumsi kategori sejarah intelektual versi Kuntowijoyo (2013:191), yaitu membahas pemikiran-pemikiran utama atau yang berpengaruh dari Fazlur Rahman. Sementara dari sifat analisisnya, penulis menggunakan analisis deskriptif (Azwar, 2014:6) dan analisis interpretatif (Bakker, 2005:41). Melalui penggunaan metodologi itu, tulisan ini diharapkan untuk menemukan dan memahami maksud dari pemikiran yang digagas oleh Fazlur Rahman sekaligus menyajikan fakta-fakta dari pemikirannya.

\section{Epistemologi dan Orientasi Intelektual}

Pemikiran reformatif Fazlur Rahman dapat dikatakan baru dimulai sejak penelitian historisnya tentang evolusi perkembangan empat sumber ajaran Islam (alquran, sunah, ijtihad, dan ijmak) sebagaimana tampak dalam buku Islamic Methodology in History. Bagi Rahman, reformasi pemikiran Islam tidak hanya sebatas kembali kepada alquran dan sunah secara tekstual-tradisional, melainkan memikirkan ulang pemahaman terhadap keduanya agar sesuai dengan konteks dan modernitas, sehingga dapat memberi pedoman bagi kehidupan masa kini. Karena, lanjut Rahman (1995:143), ketika melihat sikap generasi muslim awal terhadap alquran dan sunah, pasti ditemukan pemahaman-pemahaman yang dinamis dan hidup.

Secara umum, epistemologi pemikiran reformatif Fazlur Rahman dapat dilihat dari perkembangan intelektualnya, yang dapat dibagi menjadi tiga periode, yakni periode pembentukan (dekade 1950-an), periode perkembangan (dekade 1960-an), dan periode kematangan (dekade 1970-an sampai wafat) (Sutrisno, 2006:64). Dalam periode pembentukan, Rahman menelurkan tiga buah karya tulis, yaitu Avicenna's Psychology (1952), Avicenna's De Anima (1959) dan Prophecy in Islam: Philosophy and Orthodoxy (1958). Dua karya pertama merupakan terjemahan dan suntingan dari karya Ibn Sina (Avicenna), sedangkan yang terakhir berisi analisis komparatif pemikiran para filsuf dengan golongan ortodoks (ahli hadis) tentang doktrin kenabian.

Periode selanjutnya merupakan periode perkembangan yang ditandai oleh suatu perubahan radikal dalam diri Rahman. Dalam periode ini, Rahman membuah dua karya tulis yang kontroversial, yaitu Islamic Methodology in History (1965) dan Islam (1966). Secara umum, buku pertama berisi tentang ulasan mengenai evolusi historis perkembangan dan peran aktual empat sumber ajaran Islam dalam dinamika sejarah Islam. Sementara dalam buku yang kedua, Rahman menyajikan uraian rekonstruktif sistemis tentang sejarah perkembangan peradaban dan pemikiran Islam sejak kelahirannya hingga masa ketika dia hidup (Harianto, 2016).

Sementara periode yang ketiga adalah periode kematangan, di mana pada periode ini Rahman menulis tiga buku, yaitu The Philosophy of Mulla Sadra (1975), Major Themes of the Quran (1980) dan Islam and Modernity (1982). Pada periode ini, Rahman menggagas suatu metodologi pembaruan, yang awalnya diperuntukkan, bagi penafsiran alquran. Dalam konteks ini, Rahman (1982:145) berpolemik dengan tradisi pemikiran Islam klasik dan kontemporer, di mana dia menegaskan bahwa para pemikir muslim fundamentalis dan modernis tidak memiliki suatu metodologi eksplisit untuk memahami alquran, sehingga mereka mengambil metode tafsir secara serampangan agar sesuai dengan sikap mereka dalam persoalan tertentu. 
Nalar: Jurnal Peradaban dan Pemikiran Islam

Vol. 3, No. 1, Juni 2019

Selain itu, pada periode ketiga juga dapat dilihat, misalnya dalam buku Islam and Modernity, Rahman secara terbuka mendeklarasikan diri ikut serta dan turun terlibat dalam arus pembaruan pemikiran Islam dengan menjadikan alquran sebagai fondasi pembaruannya (Amal, 1990:136-149). Dengan begitu, Rahman mengadvokasi pendapat bahwa pembacaan langsung terhadap alquran, bukan terhadap korpus tafsir, sebagai sumber otoritatif masalah keagamaan, termasuk dalam mereinterpretasi tradisi. Meskipun, dalam hemat penulis, pemikiran-pemikiran pembaruannya telah dimulai jauh sebelum Rahman melakukan deklarasi.

Berangkat dari uraian di atas, dalam aspek epistemologi, dapat dilihat bahwa Rahman menitikberatkan metode pembaruannya pada pendekatan historis atau sejarah. Hal ini dapat dilihat dari bukunya pada periode perkembangan yang secara gamblang memberikan uraian mengenai akar sosio-historis dari perkembangan sumber ajaran Islam serta peradaban dan pemikiran Islam. Sementara dilihat dari karya Rahman pada periode kematangan, dapat dikatakan bahwa Rahman mendasari pemikirannya pada alquran dengan menempatkannya sebagai sumber terbaik bagi kehidupan individual dan kolektif. Dengan demikian, dapat disebut bahwa Rahman adalah sosok intelektual muslim yang berorientasi qurani.

\section{Krisis Intelektual dan Fenomena Gerakan Islam}

Banyak sarjana berpendapat bahwa dunia Islam berada dalam kondisi kemunduran dan krisis yang akut sejak abad ke-18. Kondisi ini diperparah oleh penguasaan Barat terhadap berbagai sektor kehidupan, baik ekonomi, politik, sosial maupun intelektual. Penguasaan yang dilakukan Barat meningkat seiring berjalannya waktu. Dalam melihat fenomena ini, Rahman memandang bahwa inti permasalahannya adalah permasalahan intelektualisme. Bagi Rahman, intelektualisme begitu penting untuk membangkitkan kembali peradaban Islam yang sudah jauh tertinggal. Rahman melihat bahwa akar kemunduran Islam disebabkan stagnasi intelektual dari masa klasik dan pertengahan yang kemudian terwariskan dan diterima secara taken for granted pada masa modern (Filaly-Ansary, 2009:214-220).

Jika dilihat dari beberapa tulisan Rahman, maka setidaknya terdapat empat faktor penyebab kemunduran Islam (Koshul, 1994:405), yakni 1) ketidakserasian hubungan antara alquran, sunah, ijmak, dan ijtihad, yang berujung pada pembakuan dan pembekuan hukum Islam sampai pada kemunculan pendapat bahwa pintu ijtihad tertutup, 2) pembebanan doktrin teologis mayoritas yang menyebabkan penyingkiran pelbagai doktrin teologis lain, sedangkan doktrin teologis mayoritas itu sendiri tidak mampu menyesuaikan dengan tuntutan perubahan zaman, 3) pemudaran semangat intelektualisme sebagaimana tampak dalam kurikulum pendidikan tinggi Islam, dan 4) mental colonizable dari kaum muslim sendiri. Dari faktor-faktor ini, kaum muslim terpaksa berbuat dengan tradisi-tradisi yang beku, terutama ketika menghadapi hegemoni Barat.

Sementara itu, jika dilihat dari realitas sosio-historis Islam sepanjang perjalanannya, ketika para penganutnya dihadapkan dengan perubahan-perubahan sosial, maka akan bertransformasi menjadi gerakan-gerakan keagamaan. Gerakan ini selalu bertitik tolak dari masalah kebenaran doktrin atau ajaran, yang kemudian dikaitkan dengan kehidupan nyata, baik individu maupun sosial. Hal ini terjadi tidak hanya ketika menghadapi perubahanperubahan dari eksternal Islam, melainkan juga dari internal Islam. Gerakan-gerakan ini dapat dikatakan sebagai jawaban, meski tidak permanen, atas kemunduran dunia Islam.

Gerakan-gerakan Islam, terutama ketika memasuki abad ke-18 hingga abad ke-20, tumbuh dan berkembang menjadi gerakan kebangkitan Islam yang memiliki semangat yang sama, yaitu perlawanan terhadap kolonialisme dan rekonstruksi umat muslim dari masa puing-puing keruntuhan, kemunduran, dan ketertinggalan. Pada era ini bermunculan gerakan 
Nalar: Jurnal Peradaban dan Pemikiran Islam

Vol. 3, No. 1, Juni 2019

Islam, yang oleh Rahman dibagi menjadi empat gerakan, yaitu 1) revivalis pramodernisme, 2) modernisme klasik, 3) neorevivalisme atau revivalis pascamodernisme, dan 4) neomodernisme. Dalam buku yang berjudul Islam and Modernity: Transformation of an Intellectual Tradition (Rahman, 1982:162-164) dan artikel-artikel lain (Amal, 1994:17-20), Rahman telah memaparkan ciri, orientasi serta kelebihan dan kelemahan dari masing-masing kelompok tersebut. Di bawah ini akan diuraikan secara padat dan ringkas mengenai tiga kelompok pertama.

Gerakan yang pertama kali muncul adalah revivalis pramodernis, yaitu suatu gerakan pembaruan yang ingin merekonstruksi spiritualitas dan moralitas Islam atas dasar langkah kembali kepada Islam awal yang puritan. Gerakan ini muncul pada abad ke-18 sampai awal abad ke-19 di Jazirah Arab yang diinisiasi oleh Muhammad bin Abdul Wahab, di India yang diinisiasi oleh Syah Waliyullah al-Dihlawi, dan di Afrika yang diinisiasi oleh Muhammad Ali al-Sanusi. Ciri utama dari gerakan ini adalah 1) memperbaiki sosio-moral umat muslim yang tengah merosot, 2) menyerukan untuk kembali pada kesejatian Islam dengan membendung takhayul, khurafat, dan bidah melalui pembacaan kitab suci secara literal-tekstual, 3) menyerukan untuk meninggalkan sikap predeterministik, 4) dalam situasi tertentu menyerukan untuk melakukan pembaruan melalui jihad, dan 5) anti-intelektualisme dan antiBarat.

Dasar pembaruan revivalis pramodernis ini, kemudian diambil oleh gerakan modernisme klasik. Gerakan ini lahir dan berkembang pada medio abad ke-19 sampai abad ke-20. Di antara tokoh-tokoh yang termasuk pada gerakan modernisme klasik adalah Ahmad Khan di India, serta Jamaluddin al-Afghani dan Muhammad Abduh di Mesir. Para tokoh ini berusaha untuk melakukan harmonisasi agama dengan modernisme dan westernisme melalui penafsiran dogma dan doktrin sesuai semangat zaman. Dengan demikian, gerakan ini berbeda langkah dengan gerakan sebelumnya dengan lebih membuka diri terhadap gagasan aktual Barat. Fokus dari gerakan ini ada pada pencarian relasi protagonistik akal dan wahyu, pembaruan sosial dan politik, kedudukan wanita, dan pembaruan hubungan Islam dan negara dalam bentuk pemerintahan yang representatif dan konstitusional.

Reaksi selanjutnya terhadap gerakan modernisme klasik datang dari neorevivalisme atau revivalisme pascamodernis. Gerakan ketiga ini muncul pada medio abad ke-20 di Saudi Arabia, anak Benua Indo-Pakistan, dan Indonesia. Menurut Rahman, para tokoh dari gerakan ini, di satu sisi mendukung ide pembaruan modernisme klasik, tapi di satu sisi kelompok ini juga berusaha membedakan diri dari Barat. Bagi neorevivalis, modernis klasik sudah terpengaruh berat oleh pemikiran dan peradaban Barat. Dengan demikian, alih-alih meneruskan apa yang telah digagas oleh modernisme klasik, gerakan neorevivalisme justru muncul secara reaktif terhadap modernisme klasik.

Berdasarkan uraian di atas, dalam pandangan Rahman ketiga gerakan tersebut masih memiliki kelemahan. Secara rinci, Rahman menyebutkan bahwa gerakan pertama dan ketiga memilih jalan ekstrem menutup diri dalam lingkaran ortodoksi tertutup, sedangkan kelompok kedua berlindung dalam objektivitas ilmiah, sehingga tidak mampu mencapai kebenaran esensial yang transenden spiritual. Faktor lain yang menjadi kelemahan ketiga gerakan ini adalah ketiadaan atau bahkan ketidakmampuan merumuskan suatu metodologi yang mumpuni untuk mengkaji Islam, terutama dari sumber-sumber autentiknya. Oleh karena itu, Rahman berusaha mencanangkan suatu penyusunan metodologi yang tepat guna dan logis sebagai pisau analisis dalam mengkaji Islam. 
Nalar: Jurnal Peradaban dan Pemikiran Islam

Vol. 3, No. 1, Juni 2019

\section{Metodologi Pembaruan: Upaya Rekonstruksi Pemikiran Islam}

Sebagai salah seorang intelektual muslim yang teramat kritis terhadap tradisi pemikiran Islam dan juga kajian Barat, Rahman berpandangan bahwa setiap bidang pemikiran Islam, yakni teologi, filsafat, dan tasawuf, memiliki historisitas dan relevansinya masingmasing. Dengan menunjukkan dinamika internal kalangan muslim awal, Rahman berpandangan, suatu tradisi pemikiran Islam yang terlepas dari akar historis dan relevansinya dengan masyarakat dianggap sebagai suatu bentuk yang tidak autentik (Madjid, 1993:23-24). Oleh karena itu, untuk menjawab tantangan perubahan situasi zaman dan kondisi masyarakat, tradisi pemikiran Islam yang dinamis, sebagaimana pada periode klasik dan pertengahan, perlu terus dipertahankan dan dikembangkan sedemikian rupa.

Atas dasar fenomena kemunduran Islam yang disertai kemunculan gerakan Islam sebagaimana telah dijelaskan, muncul sebuah pertanyaan penting yaitu bagaimana Islam sebagai warisan agama, budaya, politik, dan etika menghadapi perubahan zaman yang cepat? Sementara Islam sendiri menurut pemahaman Rahman harus diarahkan pada kehidupan nyata dan mempunyai dampak sosial yang besar. Dalam upaya menjawab pertanyaan itu, Rahman merumuskan sebuah metodologi pembaruan yang sering dikenal dengan double movement (gerakan ganda).

Secara garis besar, metodologi yang digagas oleh Rahman terdiri atas tiga pendekatan. Pertama, pendekatan historis untuk menemukan makna teks alquran dalam bentangan karir dan perjuangan Nabi; kedua, pendekatan kontekstual untuk membedakan antara ketetapan legal dengan sasaran dan tujuan alquran; dan ketiga pendekatan sosiologis untuk memafhumi dan menetapkan sasaran alquran dengan memperhatikan latar sosial masa kini (Muchsin, 2002:96). Turunan dari ketiga pendekatan ini menghasilkan metodologi gerakan ganda, yaitu bistorico-critical method dan hermeneutic method atau ada juga yang menyebutnya dengan sosiohistoris dan sintetis-logis.

Metodologi ini pada dasarnya adalah berangkat dari situasi sekarang ke masa alquran diturunkan dan kembali lagi ke masa sekarang. Masing-masing dari dua gerakan ini memiliki dua langkah. Langkah pertama dari gerakan pertama adalah memahami makna suatu pernyataan alquran yang turun sebagai jawaban melalui pengkajian situasi atau problem historisnya. Langkah kedua, membuat generalisasi dari jawaban spesifik dan mengungkapkannya dalam pernyataan yang memiliki tujuan moral-sosial yang bersifat umum. Setelah dua langkah pertama, dilanjutkan dua langkah terakhir dari gerakan kedua. Langkah pertama adalah merumuskan prinsip-prinsip, nilai dan tujuan moral-sosial yang umum ke prinsip-prinsip, nilai dan tujuan moral yang spesifik. Langkah kedua, meletakkan prinsipprinsip, nilai dan tujuan itu dalam konteks sosio-historis konkret saat ini (Rahman, 1982:5).

Dengan nada cukup optimis, Rahman yakin bahwa metodologi yang digagas dan ditawarkan mampu menghindarkan para pengkaji tradisi pemikiran Islam dari ijtihad yang serampangan. Metodologi ini diandaikan sebagai sebuah solusi untuk menjawab kebutuhan dan permasalahan Islam kontemporer, tanpa harus bertekuk lutut pada Barat atau menafikannya sama sekali. Melalui metodologi ini, Rahman berharap kaum muslim dapat mempertimbangkan dan memikirkan kembali prinsip dan nilai tradisi masa lampau untuk kemudian direkonstruksi sesuai konteks masa kini dan untuk masa depan (Rahman, 1982:141\&151).

Sehubungan dengan metodologi yang telah dikemukakan dan untuk menghidupkan kembali dinamika pemikiran Islam, Rahman membagi Islam menjadi dua kategori, yaitu Islam normatif dan Islam historis. Islam normatif adalah Islam par excellence yang terdiri atas teks dan ajaran, sedangkan Islam historis adalah pemahaman yang disertai praktik dan pelaksanaan terhadap suatu teks atau ajaran (A'la, 2003:69). Kategori kedua ini, jika ditelusuri dari berbagai 
Nalar: Jurnal Peradaban dan Pemikiran Islam

Vol. 3, No. 1, Juni 2019

karya Rahman, maka akan mengerucut pada empat bidang pemikiran Islam, yakni teologi, filsafat, tasawuf, dan fikih. Dalam hemat penulis, keempat bidang di atas yang kiranya masih memiliki lapangan terbuka untuk dipikirkan ulang. Hal fundamental yang dilakukan Rahman dalam melihat keempat bidang tersebut adalah kesesuainnya dengan pandangan alquran.

\section{Penilaian terhadap Aliran Teologi dan Dogma}

Dinamika sejarah teologi Islam, sudah dimulai sejak periode-periode awal Islam. Selama kurang lebih empat belas abad kehadiran Islam, kemunculan berbagai aliran teologi menjadi suatu konsekuensi logis. Meskipun begitu banyak silang pendapat dan ketiadaan titik temu, setidaknya hal tersebut dapat dijadikan pembelajaran untuk menyongsong masa depan. Di sini penulis hanya mengambil beberapa aliran atau tokoh dari bidang teologi Islam/ilmu kalam untuk kemudian diuraikan sekilas tentang sejarah, pemikiran, dan penilaian Fazlur Rahman terhadap masing-masing aliran atau tokoh.

Dalam menyelidiki sejarah pemikiran teologi Islam, Rahman melihat dan menilainya secara etis lewat idiom-idiom yang seutuhnya berpijak pada Islam. Dengan cara seperti ini, Rahman memandang bahwa salah satu aspek kelemahan dari teologi Islam klasik adalah pada ketidaksesuaian antara pandangan aliran-aliran teologi skolastik-spekulatif dengan pandangan dunia alquran (A'la, 2003:69). Oleh karena itu, agar suatu pemahaman teologis dapat sesuai dengan alquran, Rahman melakukan kritik dan rekonstruksi sistemik terhadap teologi klasik dan juga pertengahan, terutama yang cukup berpengaruh, baik yang rasional maupun yang ortodoks.

Aliran teologi sistematis pertama dalam sejarah Islam adalah Muktazilah. Pada mulanya, Muktazilah bukan aliran pemikir bebas dan tidak murni rasionalis. Namun, tuntutan berpikir sistematis di luar dogma, mendorong Muktazilah untuk terus mengasah penalarannya (Rahman, 2017:126). Dalam hal ini, Muktazilah berperan saat mempertahankan Islam dari pengaruh Manikheanisme, Gnostisisme, dan Materialisme. Akan tetapi, pada perkembangannya Muktazilah melangkah jauh melampaui batasan yang dapat diterima kalangan Islam tradisionalis.

Setelah serangan dari luar teratasi, Muktazilah mulai bergumul dalam wacana besar tentang keadilan dan tauhid. Dari upaya merumuskan doktrin tentang keadilan Tuhan dan tauhid semakin tampak bahwa Muktazilah menjadi pembela rasionalisme helenistik. Muktazilah mengusung kuat rasionalisme hingga menyejajarkan akal dengan wahyu dalam pencarian kebenaran agama. Sebagai contoh, doktrin kebebasan kehendak manusia yang dicanangkan Muktazilah merupakan bagian dari konsep teologi keadilan Tuhan sembari melupakan aspek asal, yaitu kebebasan dan tanggung jawab manusia, sedangkan dari sifatsifat utama Tuhan dalam alquran, yaitu kuasa, kasih, kehendak, dan keadilan, Muktazilah menonjolkan keadilan. Oleh karena itu, yang tampak ke permukaan adalah simpulan bahwa Tuhan mustahil berbuat sewenang-wenang (Rahman, 2017:126-128).

Rahman melihat, dari doktrin kebebasan kehendak manusia, bahwa Muktazilah begitu terpengaruh oleh Helenisme dan terutama Stoisme. Padahal menurut Rahman, nilai penting dari kebebasan manusia bukan terletak pada konsep kebebasan manusia itu sendiri, tetapi pada keharusan bertanggungjawab dari adanya kebebasan itu. Dengan penekanan pada aspek tanggung jawab, kebebasan manusia tidak perlu dipertentangkan dan merampas kekuasaan Tuhan (Rahman, 2017:127). Oleh sebab itu, menurut Rahman, di samping telah memberikan sumbangan memantik pemikiran dan penegasan posisi akal dalam teologi, Muktazilah juga justru terlalu berlebihan pada rasionalitas formal dan bahkan menuhankan nalar, sehingga tampak melahirkan pandangan yang ekstrem (Rahman, 2000:60-62). 
Nalar: Jurnal Peradaban dan Pemikiran Islam

Vol. 3, No. 1, Juni 2019

Aliran kedua, yaitu aliran yang bereaksi terhadap rasionalisme Muktazilah. Aliran ini dipelopori oleh Abu Hasan al-Asy'ari yang kemudian dinisbatkan namanya menjadi nama aliran. Pada dasarnya, rumusan dogma al-Asyari adalah mencoba menyintesiskan pandangan ortodoks yang terserak dengan pandangan Muktazilah. Namun, disebabkan cara kerja alAsy'ari dengan menggunakan cara kerja ortodoks, maka rumusan doktrin aliran kedua ini, separuh sintesis dan separuh reaksi (Rahman, 2017:131-132).

Terkait doktrin kebebasan manusia, al-Asy'ari berpendapat bahwa segala perbuatan diciptakan dan dihasilkan Tuhan, tetapi kebebasan itu bertaut dengan kehendak manusia yang kemudian diakuisisi. Dalam istilah lain, kekuasaan sepenuhnya milik Tuhan, sedangkan tanggung jawab tetap ada pada manusia. Sementara itu, soal kekuasaan Tuhan al-Asy'ari memunculkan teori atomistik, yaitu teori tentang alam yang menyanggah hukum sebab akibat dan potensialitas hukum alam serta menekankan efektivitas Tuhan dalam segala peristiwa, baik fisik maupun mental (Rahman, 2017:132-133). Kekuatan dari aliran Asy'ariyah ialah berhasil meneguhkan kekuasaan dan rahmat Tuhan. Akan tetapi, justru dari kekuatan ini, muncul kelemahan karena konsep kekuasaan Tuhan yang dimaksud Asy'ariyah berdampak pada pembentukan teori atomistik di kalangan ortodoks, sehingga memungkinkan akan memberangus inisiatif manusia.

Dari uraian sekilas perkembangan teologi dan dogma pada masa klasik, Rahman menemukan kelemahan dalam masing-masing aliran dan tokoh. Kelemahan utama dari teologi Islam klasik dan juga pertengahan terdapat pada persoalan metodologi. Karena itu, bagi Rahman, teologi Islam harus diposisikan sebagai usaha intelektual dan tidak boleh diklaim sebagai sesuatu yang telah final serta tidak dapat diganggu gugat. Rahman tampak menghendaki suatu teologi Islam yang membumi, di mana pembahasannya tidak hanya persoalan ketuhanan dan atribusinya, melainkan juga sinergisitasnya dengan persoalan modern-kontemporer kemanusiaan.

Secara sederhana, boleh dikatakan, jika Rahman menginginkan pembahasan teologi Islam tidak hanya sebagai sesuatu yang dipercaya dan diyakini, melainkan juga menjadi sebuah wacana keilmuan yang terus berkembang. Hal ini agar teologi Islam mampu menyikapi perubahan situasi zaman dan kondisi masyarakat. Jika demikian, maka sebuah rumusan teologi Islam harus memiliki siginifikansi terhadap kehidupan manusia, baik individu maupun sosial, sehingga tidak terasa hampa dan kering seperti kajian-kajian teologi Islam klasik dan pertengahan.

\section{Agama Filosofis: Arah Baru Gerakan Filsafat Islam}

Akar kemunculan filsafat Islam adalah teologi skolastik yang kemudian berkembang menjadi gerakan pemikiran filosofis ilmiah. Sistem filsafat Islam awal dibangun di atas gagasan filsafat Yunani atau dapat disebut juga menyimpulkan darinya, sehingga tidak heran jika materinya sangat helenistik. Meskipun demikian, konstruksi aktual dan sistemnya sendiri bercorak Islam, karena dimodifikasi sedemikian rupa hingga tampak sesuai dengan ajaran Islam. Akan tetapi, fakta sejarah menunjukkan bahwa perihal ini tidak luput dari kritikan kalangan ortodoks, sehingga bagi Rahman, filsafat Islam adalah bentuk kecemerlangan ide di satu sisi dan kemalangan nasib di sisi lain. Karena, ketika gagal memenuhi ekspektasi ortodoksi, filsafat Islam pun dijegal (Rahman, 2017:173-174).

Dalam rangkaian sejarahnya, gerakan filsafat Islam dapat dikatakan merupakan kelanjutan dari Muktazilah. Selama beberapa lama, filsafat terbukti memiliki peran urgen bagi kemajuan peradaban dan pemikiran Islam. Namun, perlu segera ditegaskan bahwa studi filsafat di dunia Islam juga mengalami pasang-surut, terutama karena kemunculan kecurigaan dari kalangan ortodoks terhadap filsafat. Salah satu yang berkomentar cukup keras terhadap 
Nalar: Jurnal Peradaban dan Pemikiran Islam

Vol. 3, No. 1, Juni 2019

rasionalitas filsuf muslim adalah al-Ghazali dalam kitabnya yang berjudul Tahâfut al-Falâsifah.

Al-Ghazali, boleh dikatakan, merupakan intelektual muslim pertama yang mengajukan tanggapan monumental dari segi kedalaman dan pengaruhnya. Akan tetapi, sebagai seorang yang menemukan kepuasan yang pasti dalam mistisisme, al-Ghazali tidak mengajukan sistem filsafat yang baru setelah mematahkan tesis para filsuf. Hal ini banyak dianggap sebagai kematian filsafat Islam. Esensi kritik al-Ghazali bukan filsafat secara keseluruhan, melainkan persoalan hubungan metafisika dan fisika yang merupakan dua bidang/cabang filsafat. Karena, bagi al-Ghazali, pada persoalan itu muncul kekeliruan pikir para filsuf, sehingga tampak berlawanan dengan ajaran Islam (Bakhtiar, 2004:7).

Beberapa tema yang dianggap oleh al-Ghazali tidak sesuai dengan ajaran Islam adalah kekadiman alam, dan kebangkitan di akhirat. Seperti mengenai kekadiman alam, bagi para filsuf muslim, alam itu kekal karena ia merupakan efek atau berasal dari Tuhan yang kekal. Ini yang kemudian dikenal dengan sebutan teori emanasi. Al-Ghazali (1972:110) berkonfrontasi dengan para filsuf muslim mengenai tesis ini, yang mana menurutnya kadim hanya milik Tuhan, karena jika ada sesuatu yang kadim selain Tuhan, maka dapat muncul semacam pernyataan retoris, "jika yang kadim banyak, maka Tuhan itu banyak."

Sementara mengenai kebangkitan di akhirat, para filsuf seperti al-Farabi, Ibn Sina, dan Ibn Rusyd mengajukan ide tentang dualisme antara jasmani dan rohani yang kemudian dimodifikasi sedemikian rupa (al-Farabi, 1959:118; Rahman, 2002:41\&82). Terkait hal ini alGhazali tidak menafikannya sama sekali. Perbedaan di antara filsuf muslim dan al-Ghazali, hanya pada sumber utama pengetahuan tentang akhirat, di mana para filsuf menempatkan otoritas akal begitu kuat, sedangkan al-Ghazali mendasarkannya pada dalil syara (al-Ghazali, 1972:287).

Ketika memandang kritikan al-Ghazali terhadap pemikiran filsuf muslim, Rahman mengapresiasi secara positif dan bahkan memuji al-Ghazali sebagai sosok yang mampu memberikan dasar spiritual bagi elan praktis moral Islam. Selanjutnya, berbeda dengan sebagian kalangan yang menganggap filsafat dalam tradisi Islam sudah mati akibat serangan al-Ghazali, Rahman justru menyanggah dengan menyatakan bahwa filsafat Islam pasca alGhazali tidak mati sama sekali, melainkan terus berkembang ke arah baru yang disebut dengan filsafat agama atau agama filosofis (Qadir, 1989; Nasr, 2001). Meskipun, harus tetap diakui terdapat efek negatif yang dirasakan dalam pengembanan studi filsafat di dunia Islam pasca serangan al-Ghazali.

Fenomena agama filosofis ini, meskipun terpengaruh oleh sufisme dan gaya pemikirannya, tetap berbeda dengan sufisme. Sebab, agama filosofis sarat dengan argumentasi rasional serta proses pemikiran yang logis dan murni intelektual. Selain itu, gerakan ini, menurut Rahman, sangat bersifat religiosentris. Tradisi agama filosofis diawali dari tokoh bernama Suhrawardi dan mencapai puncak pada masa Ibn Arabi. Doktrin utama agama filosofis adalah prinsip tingkatan wujud. Sebuah doktrin yang dikembangkan berdasarkan teori emanasi Neoplatonis. Teori lain yang terkait adalah teori kognisi yang menekankan persamaan pikiran dan wujud (Rahman, 2017:183-184).

Dalam kesempatan lain, Suhrawardi juga mengembangkan teori pengetahuan yang memandang bahwa kognisi tidak hanya terjadi melalui abstraksi forma, tetapi melalui kesadaran langsung atau kehadiran objek. Gaya pemikiran ini pada perkembangannya memengaruhi perkembangan pemikiran Islam, baik sufistik maupun filosofis. Selain itu, doktrin lain dari agama filosofis adalah doktrin idealisme fenomenologis.

Dari paparan sekilas di atas, dapat dipahami bahwa filsafat Islam tidak mengalami kematian oleh serangan al-Ghazali. Sebaliknya, filsafat Islam bertransformasi menjadi apa yang disebut Rahman dengan agama filosofis. Di luar apakah tokoh-tokoh agama filosofis ini 
Nalar: Jurnal Peradaban dan Pemikiran Islam

Vol. 3, No. 1, Juni 2019

didorong oleh keinginan berfilsafat atau keinginan memperbarui bidang tasawuf, tetapi ide Rahman menyatakan bahwa agama filosofis merupakan kelanjutan filsafat Islam patut diapresiasi. Oleh karena itu, di saat kebanyakan sarjana modern menyatakan kematian nalar dan daya pikir muslim, Rahman berhasil menganalisis sejarah filsafat Islam, sehingga historisitas filsafat Islam tampak utuh hingga sekarang.

\section{Transformasi Sufisme Klasik Menjadi Neosufisme}

Untuk melacak akar pemikiran Fazlur Rahman di bidang tasawuf, dapat diketahui dari pandangannya tentang perjalanan spiritual dalam Islam. Bagi Rahman, spiritualisme telah ada semenjak Nabi Muhammad saw. mengusung misi kenabian dan kerasulannya. Namun, para sahabat tidak mempersoalkannya. Kemungkinan karena para sahabat dikader untuk suatu tujuan moral keagamaan dan aktivismenya. Selain itu, boleh jadi para sahabat menganggap bahwa pengalaman spiritual merupakan kekhususan bagi para Nabi dan Rasul.

Dalam buku Islam, Rahman (2017:192-220) menguraikan cukup rinci mengenai sejarah sufisme. Rahman menjelaskan dari awal kemunculan tasawuf atau sufisme dari sebuah kesalehan asketis menjadi sesuatu yang disebut sufisme dengan etos yang khas, awal pelembagaan sufisme yang ditandai dengan kemunculan halakah, pengembangan jalan sufi sebagai metodologi jalan batiniah, sintesis antara sufisme dan kalam ortodoks, hubungan sufisme dan teologi sampai hubungan sufisme dan agama populer serta tarekat sufi.

Pada asal mula, Rahman termasuk salah satu intelektual kontemporer yang kurang bersimpati terhadap tasawuf. Karena bagi Rahman (2000:103-112), tasawuf terlihat menolak atau mengabaikan kehidupan duniawi, sehingga tidak peka terhadap perkembangan kehidupan masyarakat, khususnya di dunia Islam. Pendapat ini sejalan dengan pendapat yang menyatakan bahwa dalam awal sejarah kemunculan, tasawuf atau sufisme selalu tampak terasingkan. Penyebab dari keterasingan di antaranya adalah banyak doktrin yang kadang terlihat tidak masuk akal dan tidak sesuai dengan normativitas Islam, seperti praktik-praktik sufi yang berupa khalwat, dan kemunculan pengaruh luar, seperti musik dan tarian.

Sejak mendapatkan kritik, beberapa dimensi tasawuf berubah dan menyesuaikan diri dengan konteks ruang dan waktu. Bahkan, menurut Aqil Siradj (2006:16), tasawuf bertransformasi dari sebuah paham yang mengutamakan kesalehan etis dan ritual asketis menjadi paham yang juga berdimensi sosial. Selain itu, bagi Rahman, terhadap fenomenafenomena tasawuf yang mengutamakan pada keselamatan individu seperti itu dibutuhkan pembaruan dengan cara mengintegrasikan kalam ortodoks dengan sufisme dan usaha pembaruan ini telah Rahman temukan dalam sejarah panjang perkembangan tasawuf.

Seiring distingsi dan dikotomi antara ortodoksi keagamaan dengan tasawuf, sejak abad ke-3 H/9 M muncul sejumlah tokoh sufi yang dengan praktik dan ajarannya berusaha mengintegrasikan keduanya. Salah satu tokoh yang paling awal adalah al-Muhasibi. Inti ajaran dan praktik al-Muhasibi adalah bukan menghindari kehidupan lahiriah atau duniawi, tetapi menekankan setiap individu untuk terus mewaspadai kesucian niat dan mawas diri dari kepuasan diri dan berbangga diri, serta merasa paling saleh (Rahman, 2017:200).

Usaha mereformasi sufisme ini dilanjutkan oleh Junaid al-Baghdadi dengan melancarkan kritik keras terhadap klaim-klaim sufi. Al-Baghdadi menolak keabsahan maqamat dan menuduh para sufi, seperti al-Bistami tertawan khayalannya sendiri. Selain itu, alBaghdadi juga berusaha mengedepankan prinsip bahwa pengetahuan lebih utama dari gnosis dan larangan lebih utama dari kebolehan (Rahman, 2017:205-209). Pada pertengahan abad ke-10, gerakan kompromi antara sufisme dan teologi mulai tampak lebih terstruktur dan sistemis. 
Nalar: Jurnal Peradaban dan Pemikiran Islam

Vol. 3, No. 1, Juni 2019

Gerakan ini mencapai puncak pada al-Ghazali, yang kemudian menjadi landasan gerakan itu. al-Ghazali adalah sosok par excellence yang berhasil memengaruhi perkembangan Islam, bukan hanya karena pemikirannya tetapi terutama karena ajarannya yang didasarkan pengalaman pribadinya. Pengaruh al-Ghazali dalam Islam tak terperi besarnya. Al-Ghazali tidak hanya merombak Islam ortodoks di satu sisi, melainkan juga memperbarui sufisme, membersihkannya dari unsur-unsur tidak islami dan mengabdikannya pada agama ortodoks (Rahman, 2017:205-209). Dengan begitu, karakter sufisme yang asal mula hanya berkutat dalam masalah asketis dan metafisik diganti dengan karakter yang adaptif dan sesuai dengan syariah (ortodoksi keagamaan).

Melihat reformasi sufisme yang sedemikian rupa, maka terhadap bentuk baru ini Rahman menyebutnya dengan neosufisme. Menurut Rahman (2017:197-200), neosufisme adalah suatu bentuk sufisme yang diperbarui. Sementara menurut Azra (1995:25), neosufisme dapat dikatakan sebagai sebuah penegasan ulang tentang nilai-nilai Islam yang utuh, keseimbangan hidup dalam seluruh aspek kehidupan dan dalam hal ekspresi kemanusiaan. Dengan demikian, dapat disimpulkan bahwa yang disebut neosufisme adalah bentuk aktualisasi sufisme dalam ranah privat menjadi ranah publik yang disesuaikan menurut situasi dan kondisi terkini.

Beranjak dari uraian di atas, tampak bahwa bentuk neosufisme yang diinginkan oleh Rahman adalah suatu perhatian tendensius pada rekonstruksi sosial dan moral masyarakat di dunia Islam. Neosufisme harus memiliki dampak positif, bukan saja bagi kehidupan individu, melainkan juga bagi kehidupan sosial dengan cara mengadvokasi masyarakat muslim untuk mencoba, mempelajari dan bekerja keras sendiri daripada menunggu kedatangan intervensi dan pertolongan Tuhan. Perihal ini bukan berarti neosufisme kehilangan watak asketik dan etisnya, namun justru watak tersebut dijadikan landasan moral untuk kehidupan sosial yang lebih baik.

\section{Neomodernisme: Syarat Renaisans Islam}

Setelah menguraikan poin-poin tentang sejarah perkembangan pemikiran dan peradaban Islam, dalam subjudul ini penulis menguraikan tentang term neomodernisme. Dalam hemat penulis, neomodernisme Rahman, meskipun jauh digagas setelah kemunculan pelbagai pandangan dan pemikirannya terhadap pemikiran Islam, adalah suatu kerangka berpikir yang utuh dan lengkap, terdiri atas epistemologi dan metodologi, yang kemudian memengaruhi pada setiap hasil penelusurannya yang dituangkan dalam berbagai karya tulis.

Fenomena gerakan pembaruan Islam, sebagaimana yang telah dijelaskan, dianggap gagal memenuhi ekspektasi dan tuntutan perubahan zaman. Konsekuensi logis dari kegagalan ini adalah kemunculan pertanyaan penting, yaitu bagaimana Islam sebagai warisan utuh dan lengkap diperhadapkan dengan perubahan zaman yang cepat? Padahal, perubahan zaman dengan segala sisi negatifnya tetap membawa keuntungan teknologi dan ilmu pengetahuan bagi masyarakat muslim (Rahman, 2000:5). Oleh karena itu, dibutuhkan kerangka berpikir baru yang tidak mengafirmasi tanpa sikap kritis dan tidak menegasikan secara serampangan.

Dalam usaha untuk menjawab tuntutan perubahan zaman dan untuk merekonstruksi pemikiran Islam, Rahman menginisiasi sebuah gerakan baru yang disebut dengan neomodernisme. Istilah ini pertama kali dimunculkan Rahman pada salah satu artikelnya yang berjudul "Islam: Past Influence and Present Challenge", di mana istilah ini digunakan sebagai nama sebuah gerakan reformasi Islam yang digagas olehnya (1979:315-330). Secara simultan, neomodernisme adalah gerakan kembali pada dasar-dasar modernisme dan menyintesiskan pemikiran kaum revivalis, modernis, dengan tuntutan Barat (Barton, 1999:18). Titik tekan dari neomodernisme, sebagaimana terlihat pada uraian subjudul sebelumnya, tampak 
Nalar: Jurnal Peradaban dan Pemikiran Islam

Vol. 3, No. 1, Juni 2019

mengarah pada reformulasi ide-ide dasar pemikiran Islam. Dengan demikian, dapat dikatakan pula bahwa neomodernisme menampilkan sebuah citra yang bersifat revisionis.

Terkait gerakan sebelumnya, menurut Taufik Adnan Amal (1994:19-20), dalam pandangan Rahman, modernisme klasik telah benar dalam semangatnya, namun tetap memiliki kelemahan mendasar, yaitu 1) tidak menguraikan secara tuntas metode secara semiimplisit, dan 2) masalah-masalah Barat yang ditangani oleh modernisme klasik justru membuat gerakan ini terkesan sebagai agen-agen westernisasi. Kelemahan ini dimungkinkan karena peranan modernisme klasik sebagai reformis terhadap masyarakat muslim dan sekaligus sebagai kontroversialis-apologetik terhadap Barat, sehingga gagal untuk melakukan reinterpretasi yang menyeluruh, sistematis, dan utuh.

Dewasa ini, neomodernisme dipandang sebagai salah satu ide pokok dalam studi filsafat kontemporer. Kata ini sering kali dianggap mempunyai kemiripan makna dengan postmodernisme. Menurut Hanafi (2015:12-13), postmodernisme identik dengan dua hal, 1) keadaan sejarah setelah zaman modern, 2) gerakan intelektual yang mencoba untuk menggugat, bahkan mendekonstruksi pemikiran sebelumnya. Meskipun demikian, postmodernisme memiliki kelemahan, yaitu relativisme pascamodern yang terjadi, yang merupakan puncak krisis pandangan dunia modern. Krisis ini diakibatkan karena manusia modern melupakan dimensi ilahiah. Manusia modern ialah sosok promothean dalam mitologi Yunani yang secara congkak mengandalkan rasionalitas dan melepaskan diri dari ikatan kosmos (Hanafi, 2015:5).

Untuk tidak mengulangi kesalahan yang sama, neomodernisme harus mampu mengembangkan sikap kritis terhadap Barat maupun warisan-warisan sejarah sendiri. Jika kedua hal ini tidak dikaji secara obyektif, maka keberhasilan dalam menghadapi tantangan kontemporer merupakan hal yang sulit bahkan mustahil. Neomodernisme dapat dilihat pula sebagai sintesis progresif antara rasionalitas dengan tradisional; antara autentisitas teks dengan realitas sosial; antara gerakan revivalisme dan modernisme. Rahman, sebagaimana dikutip Daud Damsyik (2013:223-240), telah membuat cara kerja sistematis dari neomodernisme yang terdiri atas tiga postulat, yaitu 1) merumuskan worldview (pandangan dunia) yang setia pada alquran dan mudah dipahami kaum muslim kontemporer, 2) melakukan sistematisasi etika alquran sebagai penghubung dengan tradisi pemikiran Islam, dan 3) mereformasi tradisi pemikiran Islam yang diinspirasikan dari etika alquran dan situasi kekinian.

Dalam salah satu artikel, Rahman sebagaimana dikutip Amal (1994:19-20), menyatakan bahwa jika kaum muslim dapat mengembangkan prasyarat keyakinan diri, yaitu tanpa mengalah secara membabi-buta terhadap Barat atau menolaknya sama sekali, sehingga tidak perlu menekankan identitas yang distingtif antara Barat dan Islam sebagaimana gerakan sebelumnya. Selanjutnya, tugas utama kaum muslim adalah menggagas dan mengembangkan suatu metodologi yang tepat dan logis untuk mempelajari alquran guna mendapatkan petunjuk bagi masa depan. Metodologi yang dimaksud adalah metodologi double movement (gerakan ganda). Metodologi yang secara eksplisit digagas Rahman ini yang membedakan gerakan neomodernisme dengan gerakan-gerakan sebelumnya.

Atas dasar penjelasan di atas, dalam hemat penulis, neomodernisme berbeda dengan posmodernisme. Neomodernisme cukup aman dan tepat diposisikan sebagai sebuah gerakan pembaruan intelektual atau kerangka berpikir dibandingkan sebagai sebuah situasi dan kondisi zaman setelah masa modern. Selain itu, berkaitan dengan hal ini, Rahman dalam pandangan penulis selangkah di depan dari kalangan modernis dan tradisionalis. Rahman menguasai metodologi yang kuat sebagai buah belajar dari pendidikan Barat, dan pemikiran yang berpijak pada alquran dan iman yang kokoh. Dengan demikian, warisan yang ditinggalkan Rahman bukan hanya buah pemikiran sebagaimana yang telah dijelaskan, tetapi 
Nalar: Jurnal Peradaban dan Pemikiran Islam

Vol. 3, No. 1, Juni 2019

juga metodologi double movement, yang dapat digunakan bagi setiap bidang tradisi pemikiran Islam.

\section{Penutup}

Fazlur Rahman merupakan salah satu pemikir Islam kontemporer yang memiliki pandangan yang luas dan komprehensif. Sulit untuk memetakan pemikirannya dalam beberapa tema wacana keislaman. Poin terpenting yang perlu diketahui adalah Rahman menjadikan alquran sebagai sentral pemikiran, sehingga setiap analisis dalam disiplin apa pun akan berujung pada kesesuaiannya dengan pesan moral alquran.

Bagi penulis, Rahman menunjukkan kecermelangan berpikirnya melalui gagasan neomodernisme yang disertai metodologi pembaruan dan rekonstruksi sejarah pemikiran Islam. Metodologi pembaruan yang dikenal dengan teori gerakan ganda ini, tidak hanya sesuai dan cocok dalam penafsiran alquran mengenai ayat hukum, seperti yang terlihat dalam bukunya yang berjudul Major Themes of Quran, tetapi bisa juga merupakan pemikiran filsafat sejarah dari Rahman.

Penulis melihat terdapat paling tidak dua hal signifikan dari pemikiran Rahman yang berimplikasi, baik secara teoretis maupun praktis, dalam tradisi pemikiran Islam kontemporer. Dua hal tersebut adalah tawaran metodologi baru untuk pengembangan tradisi pemikiran Islam, dan rekonstruksi sistematis tradisi pemikiran Islam (teologi, filsafat, dan sufisme) agar sesuai dengan kebutuhan kehidupan kontemporer.

Pemikiran Rahman mengenai metodologi pemikiran Islam, telah banyak menginspirasi, baik langsung maupun tidak langsung, para pakar lainnya, seperti Nasr Hamid Abu Zayd, Abdullah Saeed, Muhammad Syahrur, dan Ziauddin Sardar. Sementara gerakan neomodernisme Rahman, jika dapat diimplementasikan oleh para sarjana muslim kontemporer, maka dapat mendekati berbagai keilmuan dan kebudayaan, terutama Barat, tanpa harus merasa inferior sama sekali. 
Nalar: Jurnal Peradaban dan Pemikiran Islam

Vol. 3, No. 1, Juni 2019

\section{Daftar Pustaka}

A’la, Abd. 2003. Dari Neomodernisme ke Islam Liberal. Jakarta: Paramadina.

Al-Farabi. 1959. Al-Madînah al-Fadhîlah. Beirut: Dar al-Masyriq.

Al-Ghazali, Abu Hamid Muhammad. 1972. Tahâfut al-Falâsifah. Kairo: Dar al-Ma’arif.

Al-Jabiri, M. Abid. 1991. Al-Turâts wa al-Hadâtsah Dirâsah wa Munâqasah. Beirut: Markaz alTsaqâfah al-Arabi.

Amal, Taufik Adnan (Peny.) 1994. Metode dan Alternatif Neomodernisme Islam Fazlur Rahman. Bandung: Mizan.

Aziz, Ahmad Amir. 2009. Pembaruan Teologi: Perspektif Modernisme Mubammad Abduh dan NeoModernisme Fazlur Rabman. Yogyakarta: Teras.

Azra, Azyumardi. 1995. Jaringan Ulama Timur Tengah dan Nusantara pada Abad XVII dan XVIII. Bandung: Mizan.

Azwar, Saifuddin. 2014. Metode Penelitian. Yogyakarta: Pustaka Pelajar.

Bakhtiar, Amsal. 2004. Pergulatan Pemikiran dalam Filsafat Islam. Jakarta: UIN Jakarta Press.

Bakker, Anton. 2005. Metodologi Penelitian Filsafat. Yogyakarta: Kanisius.

Barton, Greg. 1999. "Indonesia's Nurcholish Madjid and Abdurrrahman Wahid as Intelectual Ulama: The Meeting of Islamic Traditionalism and Modernism in Neo-Modernist Thought" dalam Islam and Christian Muslim, CSIC, Birmington, Vol. 8 No. 3.

Damsyik, Daud. 2013. "Reinterpretasi Sumber Hukum Islam: Kajian Pemikiran Fazlur Rahman" dalam Al-'Adalah, Vol. 9 No. 2 Juli 2013.

Filali-Ansary, Abdou. 2009. Pembaruan Islam Dari Mana Hendak Ke Mana?, terj. Machasin. Bandung: Mizan.

Hamid, Abdul dan Yaya. 2010. Pemikiran Modern dalam Islam. Bandung: Pustaka Setia.

Hanafi, Hassan. 1992. Al-Turâts wa al-Tajdîd Mauqifunâ min al-Turâts al-Qadîm. Beirut: AlMu assasah al-Jami `iyah li al-Dirasat wa al-Nasyr wa al-Tauzi.

Hanafi, Imam. 2015. "Mengenal Neomodernisme Islam" dalam Jurnal Madania, Vol. 5 No. 1

Harianto, Budi. 2016. "Tawaran Metodologi Fazlur Rahman dalam Teologi Islam" dalam Kontemplasi, Vol. 4 No. 2 Desember 2016.

Kuntowijoyo. 2003. Metodologi Sejarah. Yogyakarta: Tiara Wacana.

Madjid, Nurcholish. 1993. "Fazlur Rahman dan Rekonstruksi Etika al-Quran" dalam Jurnal Islamika, No. 2 Oktober-Desember 1993.

Muchsin, Misri A. 2002. Filsafat Sejarah dalam Islam. Yogyakarta: Ar-Ruzz.

Nasr, S.H. 2001. Islamic Life and Thought. T.t: ABC International Group Inc.

Rahman, Fazlur. 1979. "Islam: Past Influence and Present Challenge" dalam Alford T. Welch dan Cachia Pierre (eds.), Islam: Challenges and Opportunities. Edinburgh: Edinburgh University Press.

Rahman, Fazlur. 1982. Islam and Modernity Transformation of an Intellectual Tradition. Chicago: Chicago Press.

Rahman, Fazlur. 1995. Islamic Methodology in History. Islamabad: Islamic Research Institute.

Rahman, Fazlur. 2000. Revival and Reform in Islam: A Study of Fundamentalism. Oxford: Oneworld.

Rahman, Fazlur. 2002. Prophecy in Islam: Philosophy and Orthodoxy. London: George Allen \& Unwin Ltd.

Rahman, Fazlur. 2017. Islam Sejarah Pemikiran dan Peradaban, terj. M. Irsyad Rafsadie.Bandung: Mizan.

Qadir, C.A. 1989. Filsafat dan Ilmu Pengetahuan dalam Islam, terj. Hasan Basri. Jakarta: Yayasan Obor Indonesia. 
Nalar: Jurnal Peradaban dan Pemikiran Islam

Vol. 3, No. 1, Juni 2019

Siradj, Said Aqil. 2006. Tasawnf sebagai Kritik Sosial. Bandung: Mizan.

Sirry, Mun'im. 2015. Tradisi Intelektual Islam Rekonfigurasi Sumber Otoritas Agama. Malang: Madani.

Sutrisno. 2006. Fazlur Rahman: Kajian terhadap Metode Epistemologi dan Sistem Pendidikan. Bandung: Pustaka Setia.

Suwandi, Sarwiji. 2008. Semantik Pengantar Kajian Makna. Yogyakarta: Media Perkasa. 